\title{
IMPORTANT PLANT AREAS IN THE ARABIAN PENINSULA: 4. JABAL AJA,
}

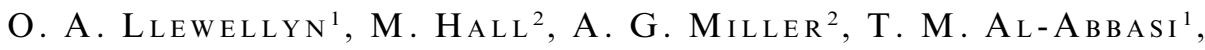

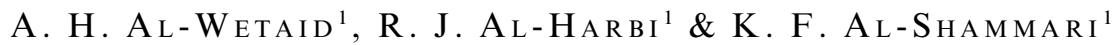

Jabal Aja' in Saudi Arabia is an Important Plant Area (IPA) in the Arabian Peninsula. This paper describes the flora of the Jabal Aja' area and provides an up-to-date botanical checklist. It designates the site as an IPA due to the presence of endemic and biogeographically relict species and the function of the site as a bioclimatic refuge. In addition to these conservation assessments, this study discusses socio-economic issues, threats to biodiversity conservation on Jabal Aja', and the future research required to build upon these preliminary studies.

Keywords. Conservation, Important Plant Area, Jabal Aja', refuge, relict species, Saudi Arabia.

\section{INTRODUCTION}

Jabal Aja' is the most prominent mountain range of Najd, the central upland region of the Arabian Peninsula. Centred at approximately $27^{\circ} 25^{\prime} 04^{\prime \prime} \mathrm{N}, 41^{\circ} 25^{\prime} 39^{\prime \prime} \mathrm{E}$ (Fig. 1) Jabal Aja' (also known as the Aja' Mts) is a long rugged maze of pink granite mountains, $100 \mathrm{~km}$ in length by $10-35 \mathrm{~km}$ wide (Fig. 2). The massif is criss-crossed by straight narrow valleys, which follow the fault lines and major jointing planes of the granite. Jabal Aja' is on the northeastern boundary of the crystalline Arabian Shield, and the Ordovician and Cambrian sandstones of the Arabian Platform. The Jabal Aja' massif and surrounding outcrops cover more than $2000 \mathrm{~km}^{2}$, with an altitude range of 900-1549 m. Jabal Aja' is cooler than most parts of Saudi Arabia, experiencing frosts in winter. It is likely that Jabal Aja' receives substantially more precipitation than the nearest meteorological station at Ha'il (see Table 1). Rain often arrives in cyclonic storms, mostly from the southwest, and falls over an average of 20 days in winter and spring when evaporation rates are low.

Flanking the western edge of the great sand desert An-Nafud, this massif is the richest site for plant biodiversity in the arid interior of the Arabian Peninsula (see below and Appendix 1). The Jabal Aja' massif has been proposed as a protected area for biodiversity conservation under Saudi legislation (Llewellyn, 1992; Abuzinada \&

\footnotetext{
${ }^{1}$ Saudi Wildlife Commission (SWC) - formerly National Commission for Wildlife Conservation and Development (NCWCD), PO Box 61681, Riyadh 11575, Kingdom of Saudi Arabia.

${ }^{2}$ Centre for Middle Eastern Plants, Royal Botanic Garden Edinburgh, 20A Inverleith Row, Edinburgh EH3 5LR, Scotland, UK. E-mail for correspondence: m.hall@rbge.ac.uk
} 


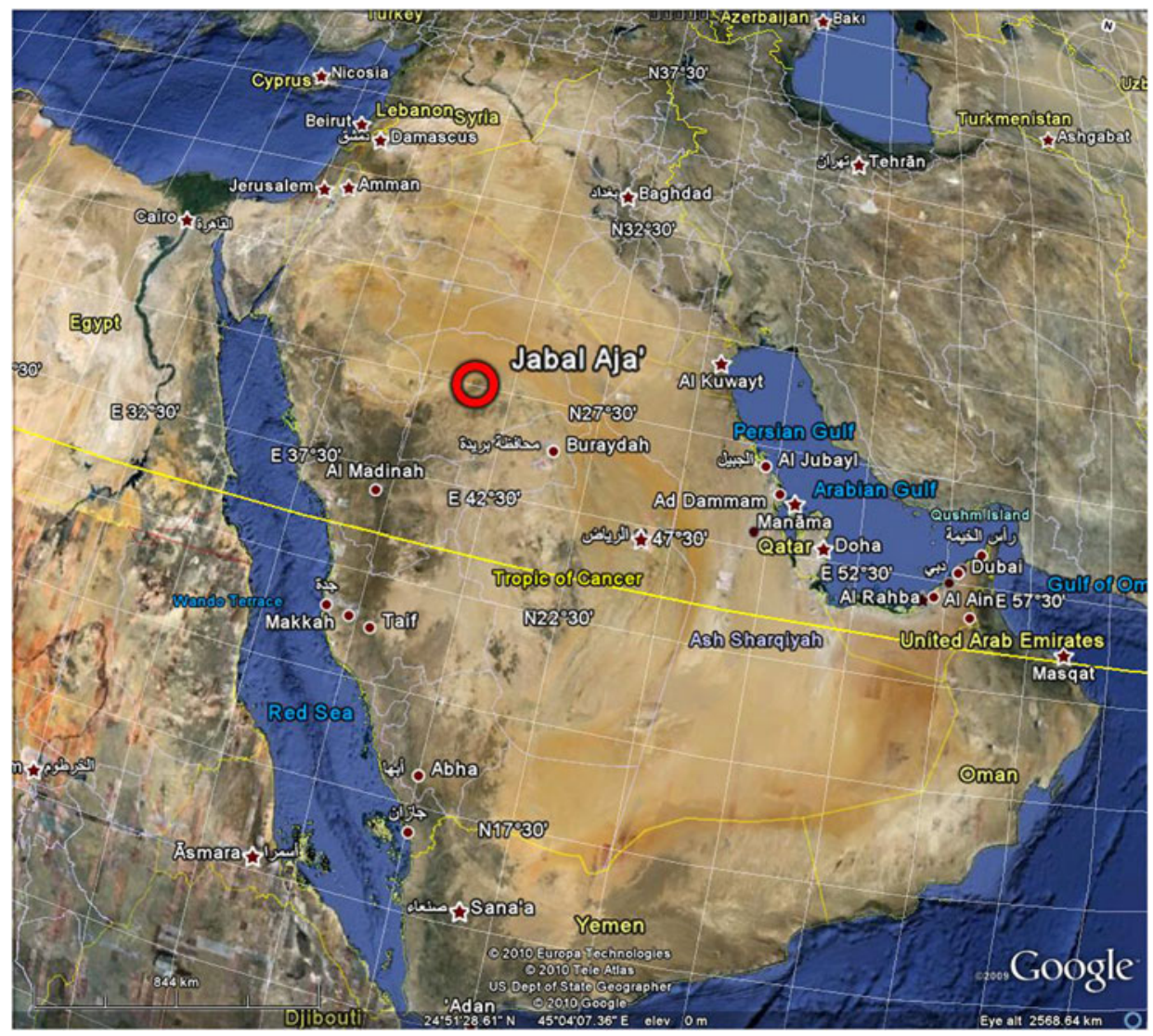

Fig. 1. Jabal Aja' is situated on the edge of the Nafud desert in northern Saudi Arabia, next to the city of Ha'il.

Llewellyn, 1997). The Saudi Wildlife Commission (SWC), formerly the National Commission for Wildlife Conservation and Development (NCWCD), has also recommended Jabal Aja' as Saudi Arabia's first Biosphere Reserve. It is one of the highest priority protected areas proposed in Saudi Arabia's protected area system plan and is now in an advanced stage of planning and design.

\section{Methodology}

The most recent field studies of Jabal Aja' were conducted for the Arabian Peninsula Important Plant Area (IPA) programme in April 2008. Survey methodology involved recording the presence of all vascular plant species at 18 selected waypoints during three days of surveying. The April 2008 IPA surveys were conducted during a time of restricted rainfall. Waypoints were therefore selected in areas of relatively good vegetation within three major topographical 'zones' in the Jabal Aja' area: the 


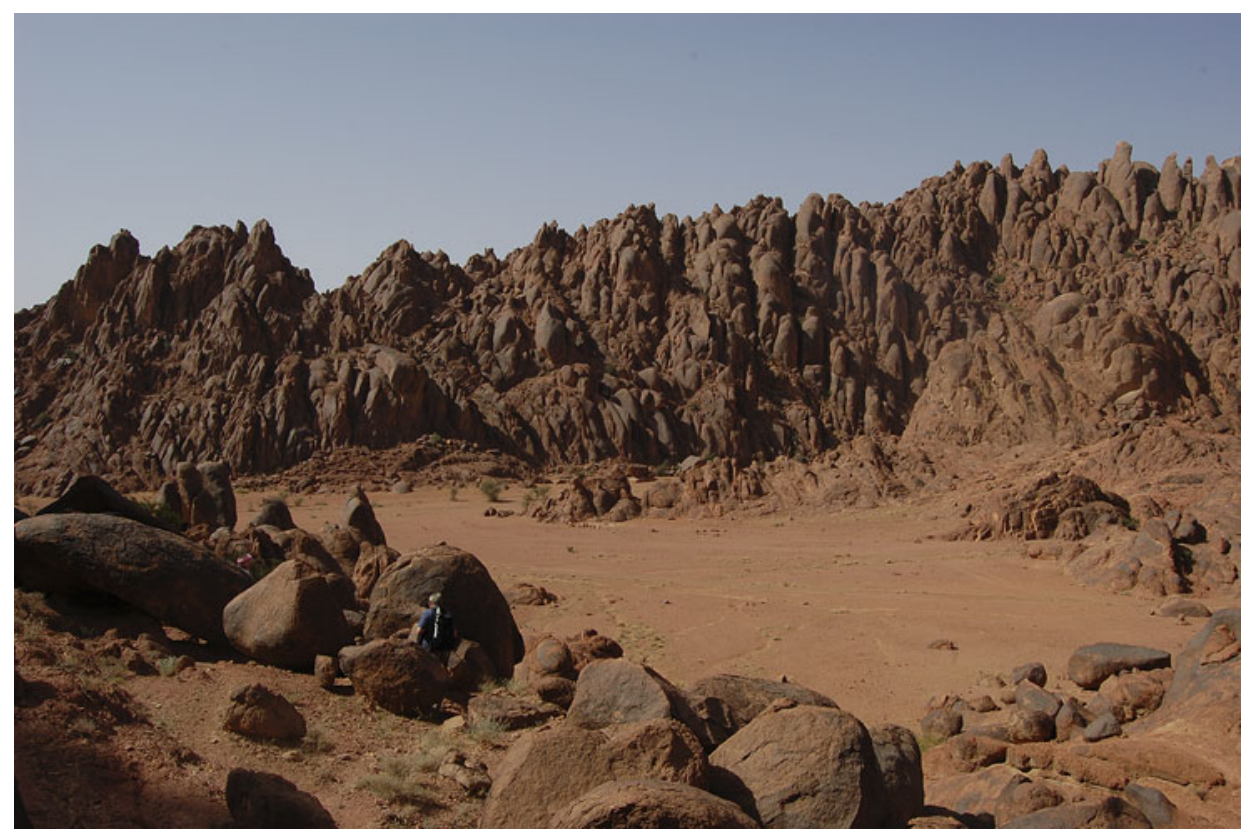

Fig. 2. Jabal Aja' is a maze of pink granite, which provides a refuge for Mediterranean and Irano-Turanian plant species in the Arabian Peninsula.

lower plains, the upper plains and slopes, and the Nafud sands. Voucher herbarium specimens and field photographs were collected and deposited at the Royal Botanic Garden Edinburgh (E). A further set of voucher specimens were deposited at the Saudi Wildlife Commission, Riyadh.

\section{RESULTS}

From the IPA surveys, Llewellyn's field records between 1986 and 1994 and from data in Collenette (1999), Collenette \& Tsagarakis (2001), Chaudhary (1999-2000) and Turki \& Al-Olayan (2003), a total of 355 plant species have been recorded in the Aja' mountains and their immediate surroundings, including the adjoining sands of the Nafud (see Appendix 1).

Phytogeographically the flora lies within the Saharo-Arabian floristic region and harbours some species of Mediterranean and Irano-Turanian origin that are relicts of the cooler Pleistocene climate. In addition to biogeographic relicts there are a number of other geographically restricted plant species, including two species endemic to the Jabal Aja' area, Trisetaria chaudharyana and Erysimum hedgeanum (for species' authors see Appendix 1). The IPA surveys in 2008 resulted in a number of new records for Jabal Aja', including Lavandula coronopifolia, Phagnalon viridifolium 
TABLE 1. Comparative measurements from seven major meteorological stations in Saudi Arabia. The nearest station to Jabal Aja' is Ha'il. Data adapted from Ghazanfar \& Fisher (1998)

\begin{tabular}{|c|c|c|c|c|c|c|c|}
\hline $\begin{array}{l}\text { Meteorological } \\
\text { station }\end{array}$ & Location & $\begin{array}{l}\text { Altitude } \\
\text { (m) }\end{array}$ & $\begin{array}{l}\text { Annual } \\
\text { rainfall } \\
(\mathrm{mm})\end{array}$ & $\begin{array}{l}\text { Maximum } \\
\text { temperature } \\
\left({ }^{\circ} \mathrm{C}\right)\end{array}$ & $\begin{array}{l}\text { Minimum } \\
\text { temperature } \\
\left({ }^{\circ} \mathrm{C}\right)\end{array}$ & $\begin{array}{l}\text { Mean } \\
\text { temperature } \\
\left({ }^{\circ} \mathrm{C}\right)\end{array}$ & $\begin{array}{l}\text { Mean } \\
\text { fog } \\
\text { days }\end{array}$ \\
\hline Ha'il & $\begin{array}{l}27^{\circ} 31^{\prime} \mathrm{N}, \\
41^{\circ} 41^{\prime} \mathrm{E}\end{array}$ & 1002 & 116 & 43.5 & -9.4 & 21.5 & 6.6 \\
\hline Riyadh & $\begin{array}{l}24^{\circ} 42^{\prime} \mathrm{N}, \\
46^{\circ} 43^{\prime} \mathrm{E}\end{array}$ & 614 & 126 & 47.4 & -4.4 & 24.8 & 5.1 \\
\hline Jeddah & $\begin{array}{l}21^{\circ} 33^{\prime} \mathrm{N} \\
39^{\circ} 10^{\prime} \mathrm{E}\end{array}$ & 4 & 47 & 49.0 & 9.8 & 28.4 & 4.8 \\
\hline Jazan & $\begin{array}{l}16^{\circ} 52^{\prime} \mathrm{N} \\
42^{\circ} 34^{\prime} \mathrm{E}\end{array}$ & 7 & 129 & 45.3 & 11.8 & 30.6 & 1.4 \\
\hline Najran & $\begin{array}{l}17^{\circ} 30^{\prime} \mathrm{N}, \\
44^{\circ} 12^{\prime} \mathrm{E}\end{array}$ & 1212 & 50 & 42.0 & -0.5 & 24.7 & 0.5 \\
\hline Tabuk & $\begin{array}{l}28^{\circ} 23^{\prime} \mathrm{N}, \\
36^{\circ} 34^{\prime} \mathrm{E}\end{array}$ & 768 & 46 & 44.4 & -3.7 & 22.0 & 0.5 \\
\hline At-Ta' if & $\begin{array}{l}21^{\circ} 16^{\prime} \mathrm{N}, \\
40^{\circ} 25^{\prime} \mathrm{E}\end{array}$ & 1453 & 204 & 39.5 & -1.2 & 22.9 & 12.1 \\
\hline
\end{tabular}

var. omanense, Scorzonera musilii, Ctenolepis cerasiformis, Cymbopogon schoenanthus, Stipagrostis ciliata and Scrophularia syriaca.

\section{Lower plains}

On the lower plains (c.900-1000 m), the soils are characterised by deep sandy and loamy calciorthids, whilst torrifluvents occupy wadi beds subject to floodwaters. From June to September, high temperatures, the lack of rainfall, as well as the winds and evaporation, result in low relative humidity and desiccated soils. This puts considerable stress on plants and animals. On these dry plains, Haloxylon salicornicum is the dominant shrub, with Citrullus colocynthis widespread, and Asphodelus tenuifolius common in runnels. Stipa tortilis, Picris cyanocarpa and Anthemis spp. are abundant after the winter rains.

In the wadis and runnels that issue into the plains from the foot of the mountains the dominant vegetation is an open Acacia gerrardii var. najdensis woodland and dwarf shrubland. Lycium shawii, usually common on wadi banks, has now mostly disappeared through overgrazing. Associated species include Pulicaria undulata (syn. P. crispa), Ochradenus baccatus and Zilla spinosa. Herbaceous species include Gypsophila capillaris, Notoceras bicorne, Rumex vesicarius, Ballota undulata, Teucrium oliverianum, Diplotaxis acris, Papaver decaisnei and Gagea reticulata.

On the slopes amongst rocks and boulders Acacia gerrardii var. najdensis is joined by Searsia tripartita (syn. Rhus tripartita) (which is relatively uncommon in Arabia), Periploca aphylla, Gymnocarpos decandrus and Ephedra foliata. The woody-based herbs Lavandula pubescens and Teucrium polium are also relatively common. 
The thin soils of the pediments at the bases of the mountains and adjacent alluvial fans and swales support vegetation mostly of small prickly species resistant to grazing: Zilla spinosa, Astragalus spinosus, Astragalus sieberi and Blepharis ciliaris. Other species include Cymbopogon schoenanthus, Cymbopogon commutatus, Stipagrostis obtusa, Pulicaria incisa, Anvillea garcinii, Trigonella stellata, Aaronsohnia factorovskyi, Roemeria hybrida, Asphodelus tenuifolius and Senna italica.

\section{Rare plant taxa}

The Saudi Arabian endemic Echinops mandavillei and the Arabian endemic variety Phagnalon viridifolium var. omanense are both recorded from the lower wadis of Jabal Aja'. Phagnalon viridifolium var. omanense has an extremely disjunct distribution in the region and is recorded from only three localities (also Jabal Akhdar Oman; Aban Al-Ahmar - Saudi Arabia).

\section{Upper plains and slopes}

Ascending the mountain range, small intermontane plains, piedmont grasslands and rocky slopes occur at approximately $1100 \mathrm{~m}$ and above (Fig. 3). Here the soils are characterised by bare rock outcrops and skeletal shallow lithosols (torriorthents) as

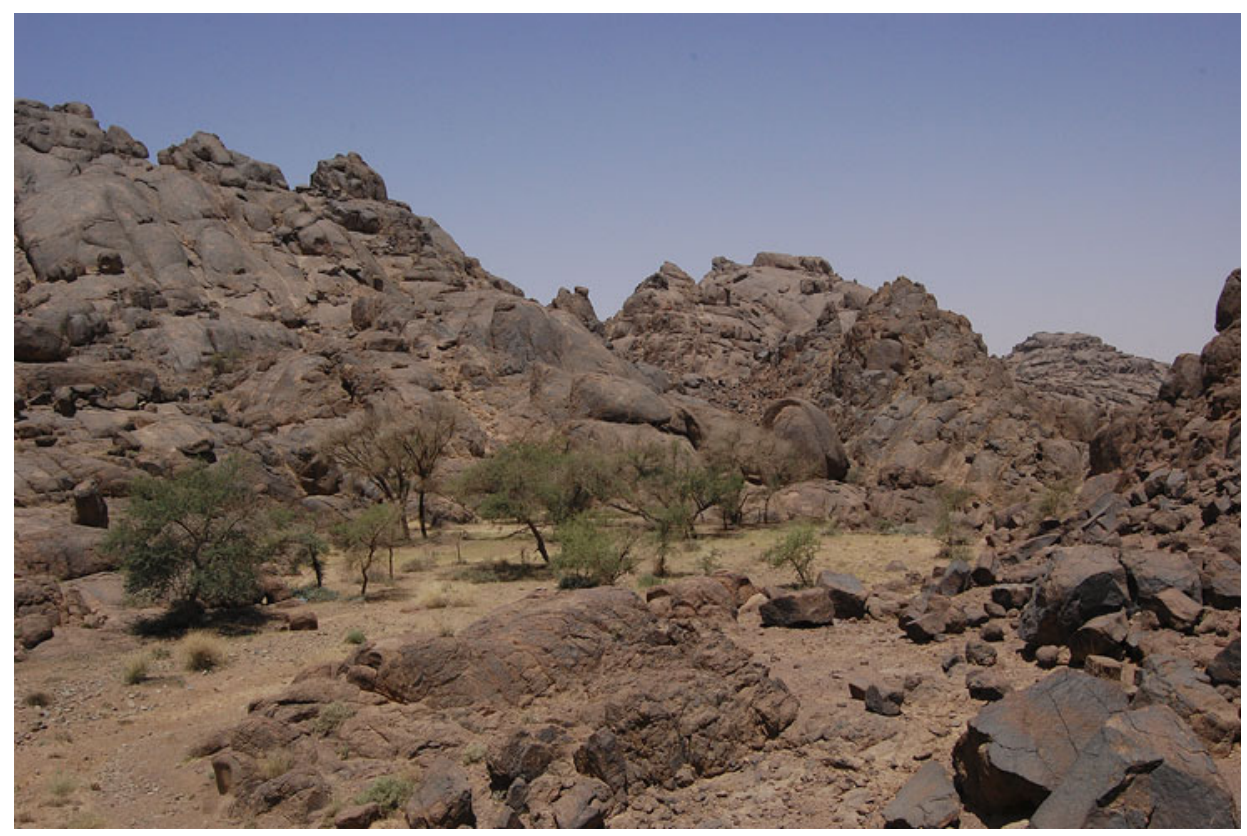

Fig. 3. The small intermontane plains, piedmont grasslands and rocky slopes above $1100 \mathrm{~m}$ on Jabal Aja' are home to a number of rare plant species including the endemic Saudi Arabian grass species Trisetaria chaudharyana. 
well as fertile meadow loams with good drainage. Small pockets of deep moistureretaining soils have gathered behind natural rock barriers and abandoned agricultural terraces. Because most of the rain that falls on the mountains runs off the impermeable granite, the zones of soil accumulation in basins, ledges and wadis receive an effective precipitation several times the actual depth of rainfall, and support abundant vegetation.

The dominant trees in these intermontane plains and ledges are Acacia gerrardii var. najdensis and Phoenix dactylifera, which can form thickets, many of them previously tended date groves (Fig. 4). The majority of these sites contain a relatively luxuriant vegetation cover. At the time of IPA field surveys in April 2008 in a number of sites

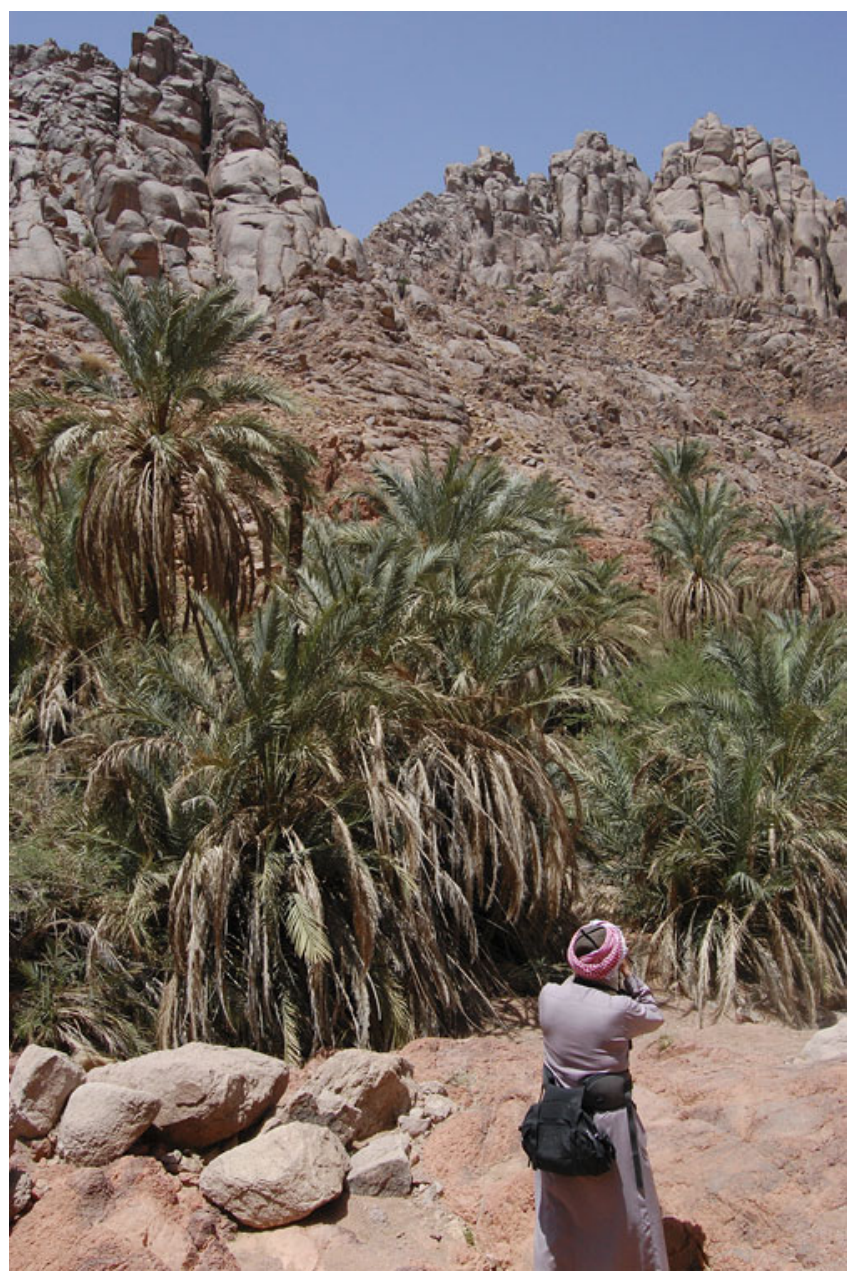

FIg. 4. Saudi Wildlife Commission's Othman Llewellyn photographing one of the many untended date groves on Jabal Aja'. 
this cover was dominated by abundant grass species, including Cymbopogon schoenanthus, Cymbopogon commutatus, Pennisetum setaceum and Hyparrhenia hirta, along with Avena barbata, Hordeum spontaneum, Hordeum murinum subsp. glaucum and Tetrapogon villosus. Prominent herbaceous species include Tribulus terrestris var. terrestris, Tribulus terrestris var. inermis, Cleome rupicola, Senecio glaucus, Ballota undulata, Rumex vesicarius, Verbascum cf. sinaiticum, Sisymbrium erysimoides, Trigonella stellata and Zoegea purpurea, Crepis spp., Salvia spp., Paracaryum rugulosum and Trichodesma ehrenbergii, along with the bulbous species Moraea (Gynandiris) sisyrinchium, Asphodelus tenuifolius and Gladiolus italicus. After spring rains these areas are abundant with a spectacular covering of annual species, most prominently Anthemis pseudocotula, Hirschfeldia incana, Isatis lusitanica, Picris cyanocarpa, Aaronsohnia factorovskyi and Diplotaxis acris.

Springs, seeps and streambeds sustain communities of Ficus palmata subsp. virgata and Phoenix dactylifera, with the fern Adiantum capillus-veneris, the sedge Scirpoides holoschoenus, and in one location Eleocharis uniglumis. Shady clefts support mosses and liverworts, the ferns Cheilanthes acrostica and Cheilanthes vellea, and herbaceous species including Galium setaceum and Arenaria foliacea.

On the surrounding slopes, Acacia gerrardii var. najdensis remains the dominant tree species, along with Searsia tripartita and Ziziphus nummularia. Common shrubs and herbs include Capparis spinosa var. mucronifolia, Astragalus spinosus, Lavandula pubescens, Lavandula coronopifolia, Teucrium polium and Heliotropium crispum (syn. H. ramosissimum). There are a few shrubs of Ochradenus arabicus, here apparently at the northwestern limit of its range.

On the higher slopes (above $1250 \mathrm{~m}$ ) of Jabal Aja' the vegetation is sparse but the dominant tree species are once again Acacia gerrardii var. najdensis and Searsia tripartita. On mountain summits and south-facing slopes, drought-resistant bunchgrasses such as Cymbopogon commutatus, Hyparrhenia hirta and Tetrapogon villosus predominate, along with Anvillea garcinii, Farsetia aegyptia, Teucrium polium and Polygala spp. On north-facing mountain slopes that are more sheltered from the sun, there are scattered shrubs of Periploca aphylla, Ochradenus baccatus, Helianthemum lippii, Gymnocarpos decandrus, Ephedra foliata, Zilla spinosa, Hibiscus micranthus, Convolvulus oxyphyllus subsp. oxycladus and Lavandula pubescens. Amongst the rocks and boulders and in small wadi channels there are a number of herbaceous species including Isatis lusitanica, Centaurea eryngioides, Astragalus spinosus, Matthiola longipetala, Helianthemum kahiricum, Asteriscus pygmaeus and Convolvulus sp. aff. pilosellifolius.

\section{Rare plant taxa}

Jabal Aja' is the only recorded site for the Saudi endemic grass Trisetaria chaudharyana, collected once from damp sand on a plateau at approximately $1400 \mathrm{~m}$. Cope (2007) records that this species is rare and is only known from the type specimen (Collenette 6167, K), but Collenette (1999) notes that this annual grass 
is locally common on Jabal Aja'. The Mediterranean-Central Asian species Thymelaea mesopotamica is also known in Saudi Arabia only from a single collection (Collenette 9130, K) from an upland ungrazed meadow near Wadi Mashar at approximately $1110 \mathrm{~m}$. The grasslands of Jabal Aja' are also one of two recorded localities in Saudi Arabia for the grass species Vulpia muralis (also in high 'Asir Mts).

Petrorhagia cretica is a Mediterranean/Irano-Turanian species only recorded in the Arabian Peninsula from alongside a wadi on the high slopes (1200 m) of Jabal Aja'. Similarly, the Irano-Turanian species Valerianella sclerocarpa (Collenette, 1999 Valerianella sp. aff. sclerocarpa) is only recorded in Saudi Arabia from a narrow steep-sided wadi at $1200 \mathrm{~m}$ on Jabal Aja' (Collenette, 1999). Valerianella oxyrhyncha is recorded on sand and in high rock crevices, at about $1200 \mathrm{~m}$ on Jabal Aja' (Collenette 5694, E). Although a widespread species in SW Asia, this is only one of two localities for the species in Saudi Arabia (also Jibal Qaraqir). Jabal Aja' is also one of two known sites in Saudi Arabia for Eleocharis uniglumis (also on Jabal Batharah/Jabal Ibrahim) and Pterocephalus brevis (Jibal Qaraqir). The Mediterranean species Noaea mucronata is recorded from only three sites in Saudi Arabia (Jabal Aja', Jabal al-Lawz and Harrat Khaybar).

\section{Nafud sands}

One of the most botanically rich sites on Jabal Aja' is at the base of the northwestern slopes $(1000-1100 \mathrm{~m})$ where the red aeolian sands of the Nafud lie up against rocky outcrops (see Fig. 5). The dominant vegetation on the sands is a sparse, open Calligonum comosum-Haloxylon salicornicum shrubland. At the base of the Aja' slopes this occurs in association with other shrubs and woody-based herbs such as Teucrium oliverianum (Fig. 6), Lavandula coronopifolia, Pterogaillonia sp. aff. calycoptera, Rhanterium epapposum, Helianthemum kahiricum, Scrophularia syriaca, Gymnocarpos decandrus, Farsetia aegyptia and Fagonia bruguieri. In the sands there is a rich flora of bulbs and annual species including Calendula arvensis, Eremobium aegyptiacum, Leysera leyseroides, Koelpinia linearis, Allium stramineum, Colchicum ritchii, Anisosciadium lanatum, Neurada procumbens and Cakile arabica, along with Cyperus conglomeratus and several grass species such as Pennisetum divisum, Stipagrostis ciliata and Stipagrostis plumosa.

Several tree-shrub species occur in sheltered areas at the very foot of the granite slopes, including Acacia gerrardii var. najdensis, Lycium shawii, Ephedra foliata, Searsia tripartita, Ochradenus baccatus and Hibiscus micranthus. In one sandy watercourse, Artemisia judaica is found; this species is reported to have been far more widespread and abundant during the past century. A playa where drainages from Jabal Aja' are blocked by the sands supports Andrachne aspera, Andrachne telephioides and Phyllanthus maderaspatensis. In sandy zones at the southwestern edge of the mountains, Rhanterium epapposum and Stipagrostis plumosa are locally dominant over wide areas. 


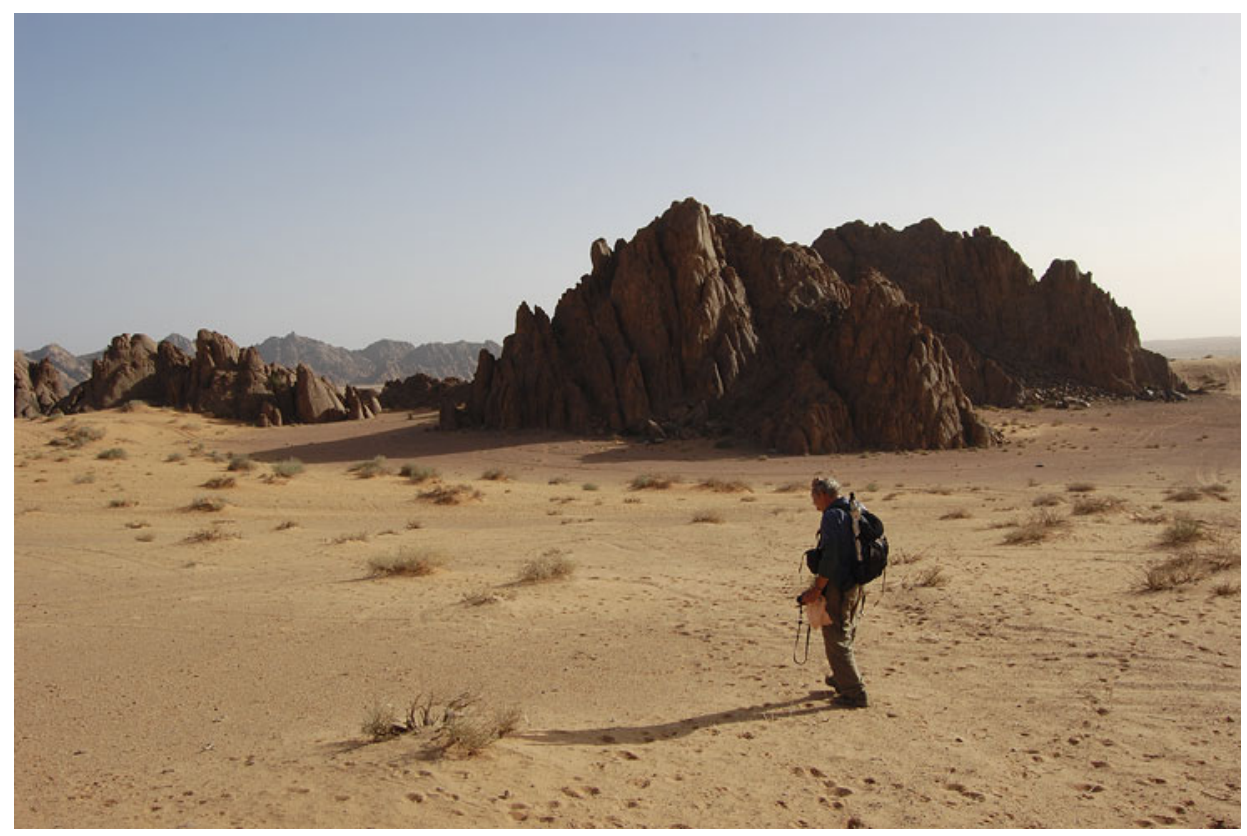

FIG. 5. Tony Miller of RBGE taking field notes in the Nafud sands at the base of the northwestern slopes of Jabal Aja'. This is one of the most botanically rich sites in the Aja' area.

\section{Rare plant taxa}

The Saudi Arabian endemic Echinops mandavillei and the Arabian endemic Phagnalon viridifolium var. omanense were both recorded from the Nafud sands at the base of Jabal Aja' by the IPA surveys. Erysimum hedgeanum is another Saudi Arabian endemic also only known from a single collection (Collenette 5713, E, K) in the sand dunes that skirt Jabal Aja'. Jabal Aja' and the adjoining Nafud sands between Jubbah and Qana' are two of three known localities (also on the Hisma Plateau) in Arabia for Muscari tenuiflorum (syn. Leopoldia tenuiflorum), which ranges from central to southeastern Europe, through Anatolia and the Transcaucasia to the Iranian Highlands (Herrmann et al., 2006). The Saudi Arabian endemic species Astragalus collenettiae is also known from the Jabal Aja' area on the southeastern fringes of the Nafud. This species is entirely restricted to the Tabuk and Ha'il regions and the northern Dahna' sands (Collenette, 1999).

\section{IPA Assessment}

Jabal Aja' is an important site for wild plant conservation. Using the Important Plant Area criteria for the Arabian Peninsula (Al-Abbasi et al., 2010) Jabal Aja' qualifies as an IPA under criteria A and B (see Table 2). 


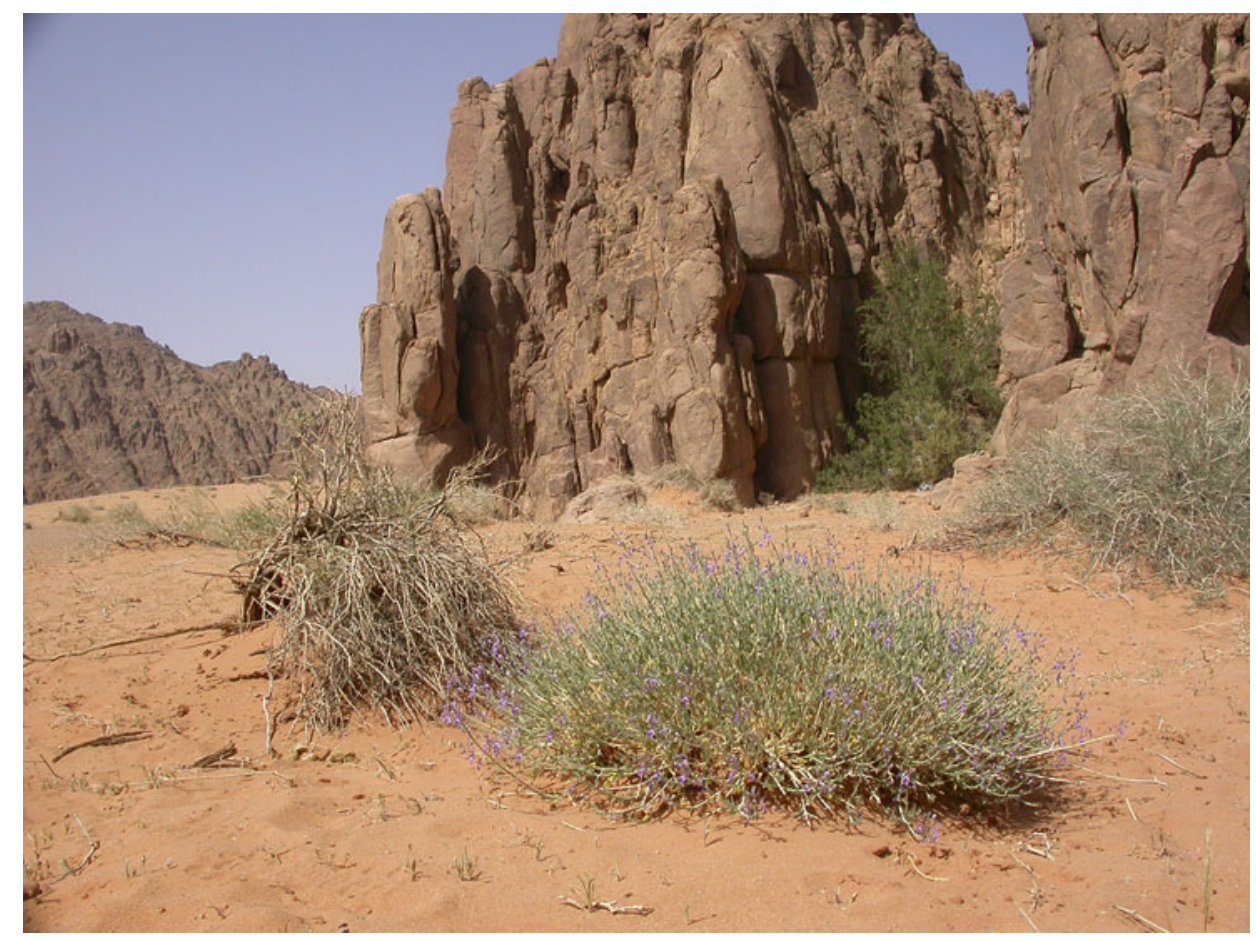

FIG. 6. Teucrium oliverianum in the red aeolian sands at the base of Jabal Aja'.

\section{OThER TAXA}

A number of significant mammal species are known from the Aja' mountains, including Nubian ibex (Capra ibex nubiana F.Cuvier), striped hyaena (Hyaena hyaena sultana Pocock), Arabian wolf (Canis lupus arabs Pocock), caracal (Caracal caracal schmitzi Matschie) and Ruppell's sand fox (Vulpes rueppelli sabaea Pocock) (Llewellyn, in press). Other prominent mammals are ratel (Mellivora capensis Schreber), rock hyrax (Procavia syriaca Hemprich \& Ehrenberg), Arabian hare (Lepus capensis arabicus Ehrenberg) and Indian crested porcupine (Hystrix indica Kerr). Jabal Aja' is listed as an Important Bird Area (IBA) (Evans, 1994) on the basis of Criterion 2iii (migratory bottleneck where $>2000$ cranes and $>3000$ raptors pass in a season: 5000-10,000 demoiselle cranes or more) and Criterion 3 (regularly holds a significant number of species that are declining or threatened in the Middle East: Griffon vulture (Gyps fulvus Hablizl), Egyptian vulture (Neophron percnopterus L.), saker falcon (Falco cherrug Gray) and eastern houbara bustard (Chlamydotis macqueenii J.E.Gray). A number of other IBA criteria are also applicable. Jabal Aja' is also an important site for herpetofauna and invertebrates (Llewellyn, in press). 
TA Ble 2. Jabal Aja' qualifies as an IPA under criteria A (1-4) and B (1 \& 2)

\section{Criterion A}

A1 - Globally threatened taxa

A2/A3 - Regionally/nationally threatened taxa

A4 - National endemic, near endemic, regional endemic and/or regional rangerestricted taxa

\section{Criterion B}

B1 - Species-rich example of a defined habitat type in Arabia

B2 - Biogeographic and bioclimatic refuge
Jabal Aja' is the only known locality for the endemic species Trisetaria chaudharyana and Erysimum hedgeanum. It is also one of three recorded sites in the Arabian Peninsula for the endemic taxon Phagnalon viridifolium var. omanense.

Due to their restricted range and the local threats to Jabal Aja' (IUCN Red List Criterion B) these species are likely to be globally threatened. IUCN Red List assessments are urgently required to determine their conservation status.

In addition to those above, 10 other rare taxa are found on Jabal Aja': Petrorhagia cretica, Thymelaea mesopotamica, Valerianella sclerocarpa, Eleocharis uniglumis, Pterocephalus brevis, Valerianella oxyrhyncha, Vulpia muralis, Clypeola aspera, Noaea mucronata and Muscari tenuiflorum.

Due to their restricted range and the local threats to Jabal Aja' (IUCN Red List Criterion B) these species are likely to be nationally/regionally threatened. IUCN Red List regional assessments are urgently required to determine their conservation status.

In addition to those mentioned above, the Arabian endemics Echinops mandavillei, Astragalus collenettiae, Ochradenus arabicus and Kickxia pseudoscoparia are also recorded from Jabal Aja'.

A species-rich desert shrubland with Calligonum and Haloxylon in the Nafud sands and species-rich piedmont grasslands in the intermontane plains of Jabal Aja'.

(a) A refuge for Mediterranean and IranoTuranian species including Petrorhagia cretica, Muscari tenuiflorum, Eleocharis uniglumis, Pterocephalus brevis, Gladiolus italicus, Thymelaea mesopotamica, Valerianella sclerocarpa, Lallemantia royleana, Valerianella oxyrhyncha, Moraea sisyrinchium, Minuartia meyeri, Centaurium erythraea, Clypeola aspera and Searsia tripartita. 
(b) The high slopes and valleys of Jabal Aja' are an important refuge for bioclimatically restricted plants to retreat to in the face of predicted increases in temperature and reductions in soil moisture (Dawson, 2007).

Jabal Aja' also acts as a seed bank 'refuge' that is strategically situated for restoration and recolonisation of surrounding degraded rangelands.

\section{Jabal Aja' and the Saudi Wildife Commission Protected Area SYSTEM PLAN}

Jabal Aja' has particular importance for the SWC protected area system plan. This mountain range is relatively cool and moist, and constitutes an important bioclimatic refuge; it harbours relict plant and animal species that were widespread during the Pleistocene but disappeared from most parts of Arabia as the climate became increasingly arid. This gives the site enhanced importance in the light of the desertification that afflicts Saudi Arabia and expected problems associated with global climate change. The SWC system plan also recognises Jabal Aja' as a natural seed bank and dispersion site that is strategically situated for restoration and recolonisation of the degraded rangelands that surround it.

With many abandoned agricultural terraces, Jabal Aja' is also recognised by SWC as a reservoir of wild crop relatives and land races (barley, oats, dates) and medicinal plants to a much greater extent than any other in the north of Saudi Arabia. Jabal Aja' also constitutes approximately one third of the area of the Jabal Shammar bioregion (Llewellyn, in press), and is the most biodiverse part of this bioregion, an important land classification used in protected area planning in Saudi Arabia.

\section{Socio-ECONOMIC IsSuES}

The city of Ha'il is situated next to Jabal Aja' and the mountain is an important recreation site for the city. Scattered farmlands occur where loamy soils and groundwater coincide. The main crops are dates, vegetables, fodders, and fruits such as peaches, pomegranates, citrons, figs and grapes. The mountain palm groves, once tended, are now nearly all neglected. Grazing by goats, sheep and camels is intensive on the flat lands and at the bases of the mountain slopes. Herds in these areas are still increasing far above the carrying capacity, yet inaccessible meadows remain vegetated. There are no known traditional himas in the Jabal Aja' area (Llewellyn, 2003) but the planned Jabal Aja' Biosphere Reserve has been proposed as a hima by WWF (Kilani et al., 2007). The site does contain numerous agricultural 
terraces, but most of these have now been abandoned and currently provide important habitats for wildlife.

Jabal Aja' is a spectacular mountain massif which potentially has a high value for tourism and recreation. The site is scenic with its numerous springs, acacia groves, abandoned palm groves, ephemeral streams and abundant wildflowers in spring. The development of nature-based tourism has the potential to benefit local communities and thus provide incentives for conservation activities. The Jabal Aja' mountains also contain sites of archaeological and cultural interest. In Tuwarin there are castle ruins and a tomb associated with the pre-Islamic personality Hatim at-Ta'iy, whilst the site of As-Sufun has archaeological petroglyphs (Llewellyn, in press).

\section{Threats To Conservation}

There are a number of existing and potential threats to the conservation of Jabal Aja' as an Important Plant Area and as a proposed protected area for biodiversity conservation. As a site adjacent to an urban population of more than 100,000, significant threats arise from expanding settlements, road construction, off-road driving, feral donkeys, agricultural expansion, cutting of trees for firewood and the construction of rubbish dumps, mines, quarries and borrow pits. The plains, wadis and more accessible parts of the mountains are severely overgrazed. Many of the wadis are degraded by continuous picnicking at popular sites. Trees are cut and topsoil is often removed in the construction of berms for privacy. Farming in some of the wadis radiating out from the mountains has increased to the point where the groundwater has become insufficient to support it (Llewellyn, in press).

At present the sites which confer IPA status on Jabal Aja' - the high piedmont grassy plains, the northwestern slopes which meet the Nafud, and the high rocky slopes - are less accessible than other parts of Jabal Aja'. As a consequence there is far less disturbance of these areas and there is a lesser threat to their conservation. However, any inappropriate development of these areas, especially if Jabal Aja' should fail to gain protected area status, has the potential to impact heavily on both species richness and the persistence of rare species.

\section{FURTHER RESEARCH}

Rapid floristic surveys have been conducted on Jabal Aja' for the IPA programme, but more in-depth studies are needed. The most recent studies have been conducted during times of prolonged drought in the Ha'il area. In order to record annual and ephemeral plants, cryptogamic plants and fungi, biodiversity assessments are required after good rainfall. Field studies are also needed in order to systematically map the areas of highest plant diversity, so that these data can be incorporated into conservation and development planning tools. As in most of the Arabian Peninsula, distribution data are required for the rare and endemic species on Jabal Aja' (Hall \& Miller, 2011). These distributions require mapping before the implementation of 
conservation monitoring programmes. Distribution mapping will also further clarify the significance of Jabal Aja' in the biogeography of Arabian plants; the site appears to represent a particularly interesting meeting point of Saharo-Arabian, Mediterranean and Irano-Turanian taxa. It may mark not only the southern/southeastern limit of the Irano-Turanian and Mediterranean plants previously mentioned, but also the northwestern limit of the range of Ochradenus arabicus.

Future research should also be directed at determining the genetic structure of the populations of Mediterranean/Irano-Turanian relict species (e.g. Petrorhagia cretica) which are only recorded in Saudi Arabia on Jabal Aja'. Such studies could assess the amount of genetic divergence between the populations on Aja' and the nearest populations located more than $500 \mathrm{~km}$ away. Following similar studies of mountain 'islands' in southern Arabia (Meister et al., 2005), analysis of this genetic variation could help determine the cause of these disjunctions. In addition, as a small, isolated population is more susceptible to inbreeding and genetic drift, research should be directed at investigating the extent to which reduced gene flow in the Jabal Aja' population has produced deleterious genetic effects. This is important from a plant conservation perspective as breeding system complications can increase extinction risk in rare species.

As well as conservation assessments, close attention needs to be paid to the implementation stage of conservation (Margules \& Pressey, 2000; Knight et al., 2007). Implementation is by far the most difficult stage of conservation activity, and in order to maximise the chances of successful biodiversity conservation a clear conservation management plan is required for Jabal Aja'. In the first instance, explicit conservation goals and objectives need to be formulated and local stakeholders such as tourism officials, agriculturalists and developers need to be engaged in the conservation planning process (Margules \& Sarkar, 2007). Stakeholders in the lands of the Jabal Aja' massif need to come together to ensure that agreed sustainable land management practices are followed. One site in the northeastern part of Jabal Aja' is proposed to be designated as a charitable foundation (waqf) for scientific research in rainwater harvesting and wildlife habitat enhancement and, in part, a seed bank to restore the biological diversity of the surrounding rangeland.

As Jabal Aja' is situated on the doorstep of a major urban centre, one strategy may be to develop innovative and engaging environmental awareness and education programmes for the residents of Ha'il. The King Abdulaziz University School of Environmental Design and the SWC have prepared a preliminary design for a wildlife park and environmental education centre on the edge of the planned protected area (King Abdulaziz University, 1993). The SWC envisages a consultative framework whereby the main stakeholders will participate as partners in the planning and management of the protected area. Jabal Aja' is proposed to be managed as Saudi Arabia's Biosphere Reserve, a protected area designed to reconcile and integrate the conservation of biological diversity with the sustainable use of natural resources (Llewellyn, 1992). Enlisting local support for biodiversity conservation will be vital to the long-term persistence of the important plant species and habitats on Jabal Aja'. 


\section{ACKNOWLEDGEMENTS}

We thank our colleagues at the Saudi Wildlife Commission for their support and assistance during this research.

\section{REFERENCES}

Abuzinada, A. H. \& Llewellyn, O. (1997). Partnerships for Wildlife Conservation and Development: A Proposed Protected Area for the Ha'il Region. Saudi Arabia: NCWCD for Ministry of Municipal and Rural Affairs Symposium.

Al-Abbasi, T. M., Al-Farhan, A., Al-Khulaidi, A. W., Hall, M., Llewellyn, O. A., Miller, A. G. \& Patzelt, A. (2010). Important Plant Areas in the Arabian Peninsula. Edinburgh J. Bot. 67: 25-35.

Angiosperm Phylogeny Group (2003). An update of the Angiosperm Phylogeny Group classification for the orders and families of flowering plants: APG II. Bot. J. Linn. Soc. 141: 399-436.

Chaudhary, S. A. (ed.) (1999-2000). Flora of the Kingdom of Saudi Arabia, Vol. 1-Vol. 2(3). Riyadh: Ministry of Agriculture and Water, National Herbarium, National Agriculture and Water Research Center.

Collenette, S. (1999). Wildflowers of Saudi Arabia. Riyadh: NCWCD.

Collenette, S. \& Tsagarakis, C. (2001). Some Regional Botanical Lists from Saudi Arabia. At-Taif/Riyadh, Saudi Arabia: National Wildlife Research Center, NCWCD.

Cope, T. (2007). Flora of the Arabian Peninsula and Socotra, Vol. 5(1) (eds S. G. Knees \& A. G. Miller). Edinburgh: Edinburgh University Press.

Dawson, T. P. (2007). Potential impacts of climate change in the Arabian Peninsula. Proceedings of the International Conference on Desertification, 12-16 May 2007, Kuwait Institute for Scientific Research (KISR), Kuwait.

Evans, M. I. (ed.) (1994). Important Bird Areas in the Middle East. Cambridge: BirdLife International.

Ghazanfar, S. A. \& Fisher, M. (1998). Vegetation of the Arabian Peninsula. London: Kluwer.

Hall, M. \& Miller, A. G. (2011). Documenting plants in a changing climate: a case study from Arabia. In: Hodk inson, T. R., Jones, M. B., Waldren, S. \& Parnell, J. A. N. (eds) Climate Change, Ecology and Systematics. Cambridge: Cambridge University Press.

Herrmann, N., Weiss, G. \& Durka, W. (2006). Biological flora of Central Europe: Muscari tenuiflorum Tausch. Flora 201: 81-101.

Kilani, H., Serhal, A. \& Llewellyn, O. (2007). Al-Hima: A Way of Life. Amman, Jordan: IUCN West Asia Regional Office, and Lebanon: SPNL Beirut.

King A bdulaziz University (1993). Wadi Mashar, Jabal Aja' Proposed Reserve: Recreational Zone, Visitors' Centre and Living Museum; Report and Master Plan with Guidelines. Department of Landscape Architecture, School of Environmental Design / NCWCD 1413.

Knight, A. T., Smith, R. J., Cowling, R. M., Desmet, P. G., Faith, D. P., FERRIER, S. et al. (2007). Improving the Key Biodiversity Areas approach for effective conservation planning. BioScience 57: 256-261.

Llewellyn, O. A. (1992). Conservation in Islamic Law. NCWCD Paper, IVth World Congress on National Parks and Protected Areas, Caracas, Venezuela.

Llewellyn, O. A. (2003). The basis for a discipline of Islamic environmental law. In: Foltz, R. C., Denny, F. M. \& Baharuddin, A. (eds) Islam and Ecology, pp. 185-247. Cambridge, MA: Harvard University Press. 
Llewellyn, O. A. (In press). Revised System Plan for Protected Areas for Wildlife Conservation and Sustainable Rural Development in Saudi Arabia. Riyadh, Saudi Arabia: Saudi Wildlife Commission.

Margules, C. R. \& Pressey, R. L. (2000). Systematic conservation planning. Nature 405: 243-253.

Margules, C. R. \& Sarkar, S. (2007). Systematic Conservation Planning. Cambridge: Cambridge University Press.

Meister, J., Hubaishan, M. A., Kilian, N. \& Oberprieler, C. (2005). Chloroplast DNA variation in the shrub Justicia areysiana (Acanthaceae) endemic to the monsoon affected coastal mountains of the southern Arabian Peninsula. Bot. J. Linn. Soc. 148: $437-444$.

Schuettpelz, E. \& Pryer, K. M. (2008). Fern phylogeny. In: Ranker, T. A. \& Haufler, C. H. (eds) Biology and Evolution of Ferns and Lycophytes, pp. 395-416. Cambridge: Cambridge University Press.

Turki, T. A. \& Al-Olayan, H. A. (2003). Contribution to the Flora of Saudi Arabia: Hail Region. Saudi J. Biol. Sci. 10: 190-222.

Received 2 February 2010; accepted for publication 18 February 2011

\section{APPENDIX 1}

Checklist of plant taxa from Jabal Aja'. Family delimitation follows APG II (Angiosperm Phylogeny Group, 2003) and Schuettpelz \& Pryer (2008)

This checklist is compiled from survey data, literature sources and herbarium specimens. The principal source for each record is noted in superscript next to each name.

1 - IPA survey data, 2008

2 - Turki \& Al-Olayan (2003)

3 - Collenette \& Tsagarakis (2001)

4 - Collenette (1999)

5 - Llewellyn unpublished survey records, 1986-1994

6 - Cope (2007)

\section{Acanthaceae}

Blepharis ciliaris (L.) B.L.Burtt ${ }^{1}$

\section{Aizoaceae}

Aizoanthemum hispanicum (L.) H.E.K.Hartmann (syn. Aizoon hispanicum L. ${ }^{3}$ )

Aizoon canariense L. ${ }^{1}$

Mesembryanthemum nodiflorum $\mathrm{L}^{3}$

\section{Alliaceae}

Allium stamineum Boiss. ${ }^{1}$

\section{Amaranthaceae}

Aerva javanica (Burm.f.) Juss. ex Schult. ${ }^{1}$ 
Amaranthus graecizans L. ${ }^{1}$

Amaranthus viridis L. ${ }^{3}$

Beta vulgaris L. ${ }^{3}$

Chenopodium murale L. ${ }^{3}$

Halothamnus iraqensis Botsch. ${ }^{2}$

Haloxylon salicornicum (Moq.) Bunge ex Boiss. ${ }^{1}$

Noaea mucronata (Forssk.) Asch. \& Schweinf. ${ }^{3}$

Salsola imbricata Forssk. $^{3}$

\section{Anacardiaceae}

Searsia tripartita (Ucria) Moffett ${ }^{1}$ (syn. Rhus tripartita (Ucria) Grande)

\section{Apocynaceae}

Gomphocarpus sinaicus Boiss. ${ }^{2}$

Pergularia tomentosa L. $^{1}$

Periploca aphylla Decne. ${ }^{1}$

Rhazya stricta Decne. ${ }^{2}$

\section{Asphodelaceae}

Asphodelus tenuifolius Cav. ${ }^{1}$

\section{Boraginaceae}

Alkanna orientalis (L.) Boiss. ${ }^{2}$

Anchusa milleri Spreng. ${ }^{2}$

Arnebia decumbens (Vent.) Coss. \& $\mathrm{Kralik}^{3}$

Arnebia hispidissima (Sieber ex Lehm.) A.DC. ${ }^{3}$

Arnebia linearifolia A.DC. ${ }^{3}$

Asperugo procumbens $\mathrm{L}^{3}$

Buglossoides arvensis (L.) I.M.Johnst. ${ }^{2}$

Echium rauwolfii Delile ${ }^{1}$ (syn. Echium arabicum R.Mill. ${ }^{3}$ )

Gastrocotyle hispida (Forssk.) Bunge ${ }^{3}$

Heliotropium crispum Desf. ${ }^{1}$ (syn. Heliotropium ramosissimum (Lehm.) DC.)

Heterocaryum szovitsianum (Fisch. \& C.A.Mey.) A.DC. ${ }^{2}$

Lappula sinaica (A.DC.) Asch. \& Schweinf. ${ }^{3}$

Lappula spinocarpos (Forssk.) Asch. ex Kuntze ${ }^{3}$

Paracaryum rugulosum (A.DC.) Boiss. ${ }^{3}$

Trichodesma africanum (L.) Sm. ${ }^{2}$

Trichodesma ehrenbergii Schweinf. ex Boiss. ${ }^{1}$

Collenette \& Tsagarakis (2001) list Anchusa aegyptiaca (L.) A.DC. from Jabal Aja', but this awaits determination of collected material. This species is not counted in the total species number for Jabal Aja'.

\section{Brassicaceae}

Alyssum homalocarpum (Fisch. \& C.A.Mey.) Boiss. ${ }^{1}$

Brassica tournefortii Gouan ${ }^{2}$

Cakile arabica Velen. \& Bornm. ${ }^{1}$

Capsella bursa-pastoris (L.) Medik. ${ }^{3}$

Cardaria draba (L.) Desv. ${ }^{3}$

Carrichtera annua (L.) DC. ${ }^{3}$

Clypeola aspera (Grauer) Turrill ${ }^{3}$ 
Clypeola jonthlaspi $\mathrm{L}^{3}$

Diplotaxis acris (Forssk.) Boiss. ${ }^{1}$

Diplotaxis erucoides (L.) DC. ${ }^{2}$

Eremobium aegyptiacum (Spreng.) Asch. \& Schweinf. ex Boiss. ${ }^{1}$

Eruca sativa Mill. ${ }^{3}$

Erysimum hedgeanum Al-Shehbaz ${ }^{1}$ (syn. Arabidopsis erysimoides Hedge \& Kit Tan)

Farsetia aegyptia Turra ${ }^{1}$

Hirschfeldia incana (L.) Lagr.-Foss. ${ }^{3}$

Isatis lusitanica $\mathrm{L}^{1}$

Lepidium aucheri Boiss. ${ }^{2}$

Malcolmia africana (L.) W.T.Aiton (syn. Strigosella africana (L.) Botsch. ${ }^{3}$ )

Matthiola longipetala (Vent.) DC. ${ }^{1}$

Morettia canescens Boiss. ${ }^{1}$

Morettia parviflora Boiss. ${ }^{3}$

Moricandia sinaica (Boiss.) Boiss. ${ }^{2}$

Neotorularia torulosa (Desf.) Hedge \& J.Léonard ${ }^{3}$

Notoceras bicorne (Aiton) Amo ${ }^{1}$

Savignya parviflora (Delile) $\mathrm{Webb}^{3}$

Schimpera arabica Hochst. \& Steud. ${ }^{3}$

Sisymbrium erysimoides Desf. ${ }^{1}$

Sisymbrium irio L. ${ }^{2}$

Sisymbrium orientale $\mathrm{L}^{3}$

Zilla spinosa (L.) Prant $1^{1}$

\section{Campanulaceae}

Wahlenbergia sp. aff. campanuloides (Delile) Vatke ${ }^{3}$

\section{Capparaceae}

Capparis decidua (Forssk.) Edgew. ${ }^{5}$

Capparis spinosa $\mathrm{L} .{ }^{1}$

\section{Caryophyllaceae}

Arenaria foliacea Turrill $^{3}$

Gymnocarpos decandrus Forssk. ${ }^{1}$

Gypsophila capillaris (Forssk.) C.Chr. ${ }^{1}$

Gypsophila viscosa Murray ${ }^{1}$

Herniaria hirsuta $\mathrm{L}^{2}$

Loeflingia hispanica $\mathrm{L}^{3}$

Minuartia meyeri (Boiss.) Bornm. ${ }^{3}$

Paronychia arabica (L.) DC. ${ }^{3}$

Paronychia chlorothyrsa Murb. ${ }^{2}$

Petrorhagia cretica (L.) P.W.Ball \& Heywood ${ }^{3,4}$

Polycarpaea repens (Forssk.) Asch. \& Schweinf. ${ }^{3}$

Polycarpaea robbairea (Kuntze) Greuter \& Burdet $^{3}$

Polycarpon tetraphyllum (L.) L. ${ }^{3}$

Pteranthus dichotomus Forssk. ${ }^{1}$

Sclerocephalus arabicus Boiss. ${ }^{3}$

Silene apetala Willd. $^{2}$

Silene arabica Boiss. $^{3}$

Silene burchellii Otth ex DC. ${ }^{2}$ 
Silene linearis Decne. ${ }^{3}$

Silene schweinfurthii Rohrb. ${ }^{3}$

Silene villosa Forssk. ${ }^{2}$

Spergula fallax (Lowe) E.H.L.Krause ${ }^{1}$

Spergularia diandra (Guss.) Heldr. ${ }^{3}$

\section{Cistaceae}

Helianthemum aegyptiacum (L.) Mill. ${ }^{3}$

Helianthemum kahiricum Delile ${ }^{3}$

Helianthemum ledifolium (L.) Mill. ${ }^{3}$

Helianthemum lippii (L.) Dum.Cours. ${ }^{1}$

\section{Cleomaceae}

Cleome amblyocarpa Barratte \& Murb. ${ }^{2}$

Cleome rupicola Vicary ${ }^{1}$

\section{Colchicaceae}

\section{Colchicum ritchii $\mathrm{R} . \mathrm{Br}^{3}$}

\section{Compositae (Asteraceae)}

Aaronsohnia factorovskyi Warb. \& Eig ${ }^{1}$

Achillea fragrantissima (Forssk.) Sch.Bip. ${ }^{2}$

Anthemis melampodina Delile ${ }^{1}$

Anthemis pseudocotula Boiss. ${ }^{2}$

Anthemis zoharyana Eig $^{4}$

Anvillea garcinii (Burm.f.) DC. ${ }^{1}$

Artemisia judaica $\mathrm{L}^{1}{ }^{1}$

Asteriscus pygmaeus (DC.) Coss. \& Durieu ${ }^{1}$

Atractylis cancellata $\mathrm{L}^{3}$

Atractylis carduus (Forssk.) C.Chr. ${ }^{1}$ (syn. Atractylis flava Desf. ${ }^{3}$ )

Calendula arvensis $\mathrm{L} .{ }^{1}$

Calendula tripterocarpa Rupr. $^{2}$

Carduus pycnocephalus $\mathrm{L}^{3}$

Carthamus nitidus Boiss. ${ }^{2}$

Carthamus oxyacantha M.Bieb. (as Carthamus oxycantha Boiss. ${ }^{2}$ )

Centaurea eryngioides Lam. ${ }^{1}$

Centaurea mesopotamica Bornm. $^{2}$

Centaurea pseudosinaica Czerep. $^{3}$

Centaurea sinaica DC. ${ }^{2}$

Chrysanthemum coronarium $\mathrm{L}^{3}$

Conyza bonariensis (L.) Cronquist ${ }^{3}$

Crepis aspera L. ${ }^{3,4}$

Crepis kotschyana (Boiss.) Boiss. ${ }^{2}$

Crepis sancta (L.) Bornm. ${ }^{3}$

Echinops mandavillei Kit Tan ${ }^{1}$

Echinops sp. ${ }^{1}$

Filago desertorum Pomel $^{1}$

Flaveria trinervia (Spreng.) C.Mohr ${ }^{3}$

Gymnarrhena micrantha Desf. ${ }^{3}$

Hedypnois rhagadioloides (L.) F.W.Schmidt ${ }^{3}$ 
Ifloga spicata (Forssk.) Sch.Bip. ${ }^{2}$

Koelpinia linearis Pall. ${ }^{1}$

Lasiopogon muscoides (Desf.) DC. ${ }^{3}$

Lasiospermum brachyglossum DC. ${ }^{2}$

Launaea fragilis (Asso) $\mathrm{Pau}^{2}$

Launaea nudicaulis (L.) Hook.f. ${ }^{3}$

Leysera leyseroides (Desf.) Maire ${ }^{1}$

Matricaria aurea (Loefl.) Sch.Bip. ${ }^{3}$

Osteospermum vaillantii (Decne.) Norl. ${ }^{2}$

Phagnalon schweinfurthii Sch.Bip. ex Schweinf. ${ }^{3}$

Phagnalon viridifolium Decne. ex Boiss. var. omanense Qaiser \& Lack ${ }^{1}$

Picris babylonica Hand.-Mazz. ${ }^{4}$

Picris cyanocarpa Boiss. $^{3}$

Pulicaria incisa (Lam.) DC. ${ }^{1}$

Pulicaria undulata (L.) C.A.Mey. (syn. Pulicaria crispa (Forssk.) Oliv. ${ }^{1}$ )

Pulicaria vulgaris Gaertn. ${ }^{3}$

Reichardia tingitana (L.) Roth ${ }^{1}$

Rhanterium epapposum Oliv. ${ }^{1}$

Scorzonera musilii Velen. ${ }^{1}$

Scorzonera papposa DC. ${ }^{3}$

Scorzonera schweinfurthii Boiss. ${ }^{2}$

Scorzonera syriaca Boiss. \& C.I.Blanche ${ }^{2}$

Scorzoneroides laciniata (Bertol.) Greuter ${ }^{1}$ (syn. Leontodon laciniatus (Bertol.) Widder)

Senecio flavus (Decne.) Sch.Bip. ${ }^{2}$

Senecio glaucus L. ${ }^{1}$

Sonchus oleraceus L. ${ }^{3}$

Zoegea purpurea Fresen. ${ }^{1}$

\section{Convolvulaceae}

Convolvulus arvensis $\mathrm{L} .^{3}$

Convolvulus sp. aff. pilosellifolius Desr. ${ }^{1}$

Convolvulus oxyphyllus Boiss. subsp. oxycladus Rech.f. ${ }^{1}$

Cuscuta planiflora Ten. ${ }^{3}$

\section{Crassulaceae}

Crassula alata (Viv.) A.Berger ${ }^{2}$

Sedum hispanicum L. $^{3}$

Umbilicus horizontalis (Guss.) DC. ${ }^{2}$

\section{Cucurbitaceae}

Citrullus colocynthis (L.) Schrad. ${ }^{2}$

Ctenolepis cerasiformis (Stocks) Hook.f. ${ }^{1}$

Cucumis prophetarum $\mathrm{L} .^{3}$

\section{Cynomoriaceae}

Cynomorium coccineum $\mathrm{L}^{2}{ }^{2}$

\section{Cyperaceae}

Cyperus conglomeratus Rottb. ${ }^{1}$

Eleocharis uniglumis (Link.) Schult. ${ }^{5}$ 
Scirpoides holoschoenus (L.) Soják ${ }^{1}$ (syn. Scirpus vulgaris L. ${ }^{3}$ )

\section{Dipsacaceae}

Lomelosia olivieri (Coult.) Greuter \& Burdet (syn. Scabiosa olivieri Coult. ${ }^{3}$ )

Lomelosia palaestina (L.) Raf. (syn. Scabiosa palaestina L. $^{3}$ )

Pterocephalus brevis Coult. ${ }^{3,4}$

\section{Ephedraceae}

Ephedra foliata Boiss. ex C.A.Mey. ${ }^{3}$

\section{Euphorbiaceae}

Chrozophora tinctoria (L.) A.Juss. ${ }^{3}$

Euphorbia chamaepeplus Boiss. \& Gaill. ${ }^{3}$

Euphorbia granulata Forssk. ${ }^{2}$

Euphorbia hirta L. ${ }^{3}$

Euphorbia peplus L. $^{2}$

Euphorbia schimperiana Scheele ${ }^{2}$

\section{Gentianaceae}

Centaurium erythraea Rafn (syn. Centaurium pulchellum (Swartz) Druce ${ }^{3}$ )

\section{Geraniaceae}

Erodium laciniatum (Cav.) Willd. ${ }^{3}$

Erodium neuradifolium Delile ex Godr. ${ }^{3}$

Erodium touchyanum Delile ex Godr. ${ }^{2}$

Geranium biuncinatum Kokwaro ${ }^{2}$

Geranium mascatense Boiss. ${ }^{2}$

Geranium molle L. ${ }^{3}$

Geranium rotundifolium $\mathrm{L}^{3}$

\section{Gramineae (Poaceae)}

Aegilops kotschyi Boiss. ${ }^{3}$

Aristida adscensionis L. ${ }^{3}$

Avena barbata Pott ex Link ${ }^{1}$

Avena sterilis L. ${ }^{2}$

Brachypodium distachyum (L.) P.Beauv. ${ }^{2}$

Bromus danthoniae Trin. ex C.A.Mey. ${ }^{2}$

Bromus fasciculatus C.Presl ${ }^{2}$

Bromus madritensis L. ${ }^{3}$

Bromus rubens L. ${ }^{3}$

Bromus tectorum L. ${ }^{3}$

Cenchrus ciliaris $\mathrm{L}^{2}$

Cenchrus pennisetiformis Hochst. \& Steud. ${ }^{2}$

Centropodia fragilis (P.Guinet \& Sauvage) Cope $^{2}$

Cutandia memphitica (Spreng.) K.Richt. ${ }^{2}$

Cymbopogon commutatus (Steud.) Stapf ${ }^{2}$

Cymbopogon schoenanthus (L.) Spreng. ${ }^{1}$

Cynodon dactylon (L.) Pers. ${ }^{3}$

Enneapogon desvauxii P.Beauv. ${ }^{2}$

Enneapogon persicus Boiss. (syn. Enneapogon schimperianus (Hochst. ex A.Rich.) Renvoize ${ }^{2,6}$ ) 
Eragrostis barrelieri Daveau ${ }^{3}$

Hordeum murinum L. subsp. glaucum (Steud.) Tzvelev ${ }^{3}$

Hordeum spontaneum K.Koch ${ }^{3,4}$

Hyparrhenia hirta (L.) $\mathrm{Stapf}^{2}$

Lamarckia aurea (L.) Moench ${ }^{3}$

Oropetium capense Stapf $^{3}$

Pennisetum divisum (J.F.Gmel.) Henrard ${ }^{1}$

Pennisetum setaceum (Forssk.) Chiov ${ }^{1}$

Phalaris minor Retz. ${ }^{3}$

Piptatherum holciforme (M.Bieb.) Roem. \& Schult. (syn. Oryzopsis holciformis (M.Bieb.)

Hack. $^{3}$ )

Polypogon monspeliensis (L.) Desf. ${ }^{3}$

Rostraria cristata (L.) Tzvelev ${ }^{2}$

Rostraria pumila (Desf.) Tzvelev²

Schismus arabicus $\mathrm{Nees}^{3}$

Schismus barbatus (L.) Thell. ${ }^{2}$

Stipa capensis Thunb. ${ }^{2}$

Stipagrostis ciliata (Desf.) De Winter ${ }^{1}$

Stipagrostis hirtigluma (Steud. ex Trin. \& Rupr.) De Winter ${ }^{2}$

Stipagrostis obtusa (Delile) $\mathrm{Nees}^{3}$

Stipagrostis plumosa (L.) Munro ex T.Anderson ${ }^{1}$

Tetrapogon villosus Desf. ${ }^{3}$

Themeda triandra Forssk. ${ }^{1}$

Trisetaria chaudharyana $\mathrm{H} . \mathrm{Scholz}^{2}$

Vulpia muralis (Kunth) Nees ${ }^{4}$

\section{Hyacinthaceae}

Muscari tenuiflorum Tausch (syn. Leopoldia tenuiflora (Tausch) Heldr. ${ }^{3,4}$ )

\section{Iridaceae}

Gladiolus italicus Mill. ${ }^{1}$

Moraea sisyrinchium (L.) Ker Gawl. (syn. Gynandriris sisyrinchium (L.) Parl. ${ }^{1}$ )

\section{Juncaceae}

Juncus bufonius $\mathrm{L}^{3}$

\section{Labiatae (Lamiaceae)}

Ballota undulata (Sieber ex Fresen.) Benth. ${ }^{1}$

Lallemantia royleana (Benth.) Benth. ${ }^{2}$

Lavandula coronopifolia Poir. ${ }^{1}$

Lavandula pubescens Decne. ${ }^{1}$

Mentha longifolia (L.) L. ${ }^{3}$

Micromeria imbricata (Forssk.) C.Chr. ${ }^{3}$

Salvia aegyptiaca L. ${ }^{1}$

Salvia deserti Decne. ${ }^{3}$

Salvia lanigera Poir. ${ }^{3}$

Salvia spinosa L. ${ }^{1}$

Teucrium oliverianum Ging. ex Benth. ${ }^{1}$

Teucrium polium $\mathrm{L}^{1}$ 


\section{Leguminosae}

Acacia gerrardii Benth. var. najdensis Zohary ${ }^{1}$

Astragalus collenettiae Hedge \& Podl. ${ }^{3}$

Astragalus crenatus Schult. ${ }^{3}$

Astragalus hamosus $\mathrm{L}^{2}$

Astragalus schimperi Boiss. ${ }^{3}$

Astragalus sieberi DC. ${ }^{1}$

Astragalus spinosus (Forssk.) Muschl. ${ }^{1}$

Astragalus tribuloides Delile ${ }^{2}$

Hippocrepis constricta Kunze $^{3}$

Hippocrepis unisiliquosa L. subsp. bisiliqua (Forssk.) Bornm. ${ }^{3}$

Lotononis platycarpa (Viv.) Pic.Serm. ${ }^{3}$

Medicago laciniata (L.) Mill. ${ }^{2}$

Medicago truncatula Gaertn..$^{3,4}$

Onobrychis ptolemaica (Delile) DC. ${ }^{1}$

Ononis sicula Guss. ${ }^{3}$

Senna italica Mill. ${ }^{1}$

Trigonella glabra Thunb. (syn. Trigonella hamosa L., nom. rej. ${ }^{3}$ )

Trigonella stellata Forssk. ${ }^{1}$

Vicia monantha Retz. ${ }^{3}$

\section{Liliaceae}

Gagea circumplexa Vved. (syn. Gagea dayana Chodat \& Beauverd var. conjugens (Pascher) Heyn \& Dafni $\left.{ }^{4}\right)$

Gagea reticulata (Pall.) Schult. \& Schult.f. ${ }^{2}$

\section{Linaceae}

Linum sp. ${ }^{4}$

\section{Lythraceae}

Lythrum hyssopifolia $\mathrm{L}^{4}$

\section{Malvaceae}

Althaea ludwigii L. ${ }^{3}$

Hibiscus micranthus L. ${ }^{1}$

Malva parviflora $\mathrm{L}^{2}{ }^{2}$

\section{Moraceae}

Ficus palmata Forssk. $^{2}$

Ficus palmata Forssk. subsp. virgata (Roxb.) Browicz ${ }^{1}$

\section{Myrsinaceae}

Anagallis arvensis L. ${ }^{1}$ (syn. Anagallis arvensis var. caerulea (L.) Gouan ${ }^{3}$ )

\section{Neuradaceae}

Neurada procumbens L. ${ }^{1}$

\section{Nitrariaceae}

Peganum harmala $\mathrm{L}^{2}$ 


\section{Nyctaginaceae}

Boerhavia repens $\mathrm{L}^{3}$

\section{Orobanchaceae}

Cistanche phelypaea (L.) Cout. ${ }^{3}$

Orobanche aegyptiaca Pers. ${ }^{5}$

Orobanche cernua Loefl. $^{3}$

Collenette \& Tsagarakis (2001) list Orobanche ramosa? from Jabal Aja', but this awaits determination of collected material. This species is not counted in the total species number for Jabal Aja'.

\section{Oxalidaceae}

Oxalis corniculata L. $^{5}$

\section{Palmae}

Phoenix dactylifera L. $^{1}$

\section{Papaveraceae}

Fumaria parviflora Lam. ${ }^{3}$

Hypecoum pendulum $\mathrm{L}^{1}$

Papaver decaisnei Hochst. \& Steud. ex Elkan. ${ }^{3}$

Papaver dubium $\mathrm{L}^{3}$

Roemeria hybrida (L.) DC. ${ }^{1}$

\section{Phyllanthaceae}

Andrachne aspera Spreng. ${ }^{2}$

Andrachne telephioides $\mathrm{L}^{3}$

Phyllanthus maderaspatensis L. ${ }^{3}$

\section{Plantaginaceae}

Kickxia acerbiana (Boiss.) Täckh. \& Boulos ${ }^{2}$

Kickxia aegyptiaca (L.) Nábělek ${ }^{2}$

Kickxia pseudoscoparia V.W.Sm. \& D.A.Sutton ${ }^{3}$

Linaria simplex (Willd.) Desf. ${ }^{3}$

Misopates orontium (L.) Raf. ${ }^{1}$ (syn. Antirrhinum orontium L. ${ }^{3}$ )

Plantago afra $\mathrm{L}^{2}$

Plantago amplexicaulis Cav. ${ }^{1}$

Plantago boissieri Hausskn. \& Bornm. ex Bornm. ${ }^{3}$

Plantago ciliata Desf. $^{3}$

Plantago coronopus $\mathrm{L}^{2}$

Plantago ovata Forssk. ${ }^{2}$

Veronica anagallis-aquatica $\mathrm{L}^{3}$

Veronica anagalloides Guss. ${ }^{4}$

\section{Plumbaginaceae}

Limonium lobatum (L.f.) Chaz. ${ }^{1}$

\section{Polygalaceae}

Polygala abyssinica R.Br. ex Fresen. ${ }^{1}$

Polygala negevensis Danin ${ }^{2}$ 
Polygala schwartziana Paiva $^{3}$

\section{Polygonaceae}

Calligonum comosum L'Hér. ${ }^{1}$

Emex spinosa (L.) Campd. ${ }^{3}$

Polygonum sp. aff. argyrocoleon Steud. ex Kunze ${ }^{3}$

Rumex nervosus Vahl ${ }^{1}$

Rumex vesicarius L. $^{1}$

\section{Portulacaceae}

Portulaca oleracea L. $^{3}$

\section{Pteridaceae}

Adiantum capillus-veneris L. ${ }^{5}$

Cheilanthes acrostica (Balb.) Tod. (syn. Cheilanthes pteridioides (Reichard) C.Chr. ${ }^{3}$ )

Cheilanthes vellea (Aiton) F.Muell. (syn. Cosentina vellea (Aiton) Tod. ${ }^{3}$ )

\section{Resedaceae}

Caylusea hexagyna (Forssk.) M.L.Green ${ }^{1}$

Ochradenus arabicus Chaudhary et al. ${ }^{2}$

Ochradenus baccatus Delile ${ }^{1}$

Oligomeris linifolia (Vahl) J.F.Macbr. ${ }^{3}$

\section{Rhamnaceae}

Ziziphus nummularia (Burm.f.) Wight \& Arn. ${ }^{1}$

Ziziphus spina-christi (L.) Desf. ${ }^{1}$

\section{Rubiaceae}

Callipeltis cucullaris (L.) DC. ${ }^{2}$

Galium ceratopodum Boiss. ${ }^{3}$

Galium setaceum Lam. $^{3}$

Pterogaillonia sp. aff. calycoptera (Decne.) Lincz. ${ }^{1}$ - collections of this widespread and variable species from Jabal Aja' are morphologically distinct. Further taxonomic studies may well delimit these as a separate species.

\section{Santalaceae}

Thesium humile $\mathrm{Vahl}^{3}$

\section{Scrophulariaceae}

Scrophularia deserti Delile ${ }^{3}$

Scrophularia syriaca Benth. ${ }^{1}$

Verbascum cf. sinaiticum Benth. ${ }^{1}$

\section{Solanaceae}

Hyoscyamus muticus L. $^{2}$

Hyoscyamus pusillus $\mathrm{L}^{2}$

Lycium shawii Roem. \& Schult. ${ }^{1}$

Solanum forskalii Dunal (syn. Solanum villosum Forssk. ${ }^{3}$ )

Solanum nigrum $\mathrm{L}^{2}{ }^{2}$

Withania somnifera (L.) Dunal ${ }^{3}$ 


\section{Tamaricaceae}

Tamarix aphylla (L.) H.Karst. ${ }^{5}$

Tamarix nilotica (Ehrenb.) Bunge ${ }^{5}$ (syn. Tamarix arabica Bunge)

Thymelaeaceae

Thymelaea mesopotamica (C.Jeffrey) B.Peterson ${ }^{3,4}$

Umbelliferae (Apiaceae)

Anisosciadium lanatum Boiss. ${ }^{1}$

Ducrosia anethifolia (DC.) Boiss. ${ }^{3}$

Ferula communis L. ${ }^{1}$

Scandix pecten-veneris $\mathrm{L}^{3}$

Torilis leptophylla (L.) Rchb.f. ${ }^{3}$

Urticaceae

Forsskaolea tenacissima L. $^{1}$

Parietaria alsinifolia Delile ${ }^{1}$

Valerianaceae

Valerianella oxyrhyncha Fisch. \& C.A.Mey. ${ }^{2}$

Valerianella sclerocarpa Fisch. \& C.A.Mey. ${ }^{1}$

\section{Zygophyllaceae}

Fagonia bruguieri DC. ${ }^{1}$

Fagonia glutinosa Delile ${ }^{3}$

Fagonia indica Burm.f. ${ }^{3}$

Seetzenia lanata (Willd.) Bullock ${ }^{3}$

Tribulus terrestris L. var. terrestris ${ }^{1}$

Tribulus terrestris L. var. inermis Boiss. ${ }^{1}$ 